<症例報告 $>$

少量のアセトアミノフェン服用による急性肝障害の 2 例

\begin{tabular}{|c|c|c|c|c|c|c|}
\hline 安永 & 满 & 松田 & 彰史 & 村田 & 誠 & 荻野 \\
\hline 門 & 祐二 & 新開 & 泰司 & 名和田 & 浩 & 半田 \\
\hline 野田 & 健一 & 福本 & 陽平 & 沖田 & 極 & 竹本 \\
\hline
\end{tabular}

要 旨：アセトアミノフェンの大量服用により, 急性肝障害の発症をみることは, よく知られ た事実である. 最近, 教室では, 少量のアセトアミノフェンの服用にるかかわらず, 重症肝障 害を生じた 2 例を経験したので報告した。患者は38歳の男性と31歳の女性である。アセトアミ ノフェン服用量は, それぞれ，3.7g と6.4gで, いずれも呕吐, 腹痛, 全身倦急感を訴えて入院 した，本剤服用時，前者はアルコールを摂取し，後者は絶食状態であった。検查上，前者は著 明な血清トランスアミナーゼの上犁, 軽度の黄㡺を認め, 心内膜炎, 腎障害, 急性荤炎を併発 し, 肝組織では小葉内に巣状壊死が散在し, 中心静脈周囲にも壊死が認められた. 後者でも重 篤な肝障害と血小板减少がみられ, 肝組織像は bridging necrosisを示していた.フルコール摄 取と絶食のために, 少量のフセトフミノフェン服用にもかかわらず, 予想以上に肝障害が重症 化したと考えられ，本剤の使用にあたり，注意が必要である.

事引用語： アセトフミノフェン肝障害 アルコール 絶食 グルカエ゙ン・インスリ 療法

\section{緒言}

フセトアミノフェンは，速效性の鎮痛解熱蝺で， フ スピリンのように血小板機能に影響を与えたり，消化 管出血をおこしたりすることがないために，それを処 方する機会が増加している。しかし，1966年の英国の 報告1以来, 本剂の大量投与により，致死的な肝壊死を 生ずることが証明されている．欧米諸国では，本剤に よる肝障害について多数の報告があり，このたび，著 者らは，通常では肝障害をおこし難いはどの，少量の フセトフミノフェンで, 重症の肝障害を生じた 2 例を 経鈳したので, 若干の文献的考察をくわえて報告する.

$$
\text { 症例 }
$$

症例 $1 ； 38$ 葴, 男性.

昭和54年 7 月30日，午後 6 時頃，自殺の目的で， フ セトフミノフェン3.7gをアルコールとともに服用し た。翌朝，覚醒し，呕吐と右季助部痛を訴え，近医に 入院した。 8 月 2 日， $39.1^{\circ} \mathrm{C}$ 発熱，乏尿およびター 几便が出現し，失見当識を認めた。翌日，胸痛を訴之， 心電図でST が上昇していたため，8月 4 日,当科に入

- 山口大学医学部第 1 内科

＜受付日59年 8 月24日 $>$
院となった。

入院時, 意識は清明で, 神経学的な異常はなかった。 軽度の黄疾，ギャロップリズムを認めたが，肝脾腫は なく、肺にも著変はなかった。

入院時検查所見を Table 1にしめす. GOT 6,600u， GPT $3,010 \mathrm{u}$ ，と著しく上昇し，総ビリルビン $2.2 \mathrm{mg} /$ $\mathrm{d} l$, コレステロール $55 \mathrm{mg} / \mathrm{d} l$ と重篤な肝障害を認め た. 消化管出血のためか, アルブミンは $2.4 \mathrm{~g} / \mathrm{d} l$ と低下 していた. BUN $29.9 \mathrm{mg} / \mathrm{d} l$, クレアチニン $4.6 \mathrm{mg} / \mathrm{d} l$ と上昇していた。

入院後,アセトフミノフェンによる急性重症肝障害, 腎障害および心内膜炎と診断し，肝再生を促進する目 的で，クルカゴン・インスリン療法2,3)を開始した，8

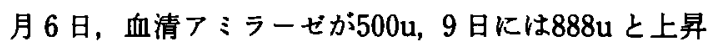
し，急性膵炎を併発した。 8 月10日より，39.6 $\mathrm{C}$ の発 熱および排尿痛が出現し，尿路感染症を認めたため CB-PCを投与したが，その後すぐに解熱し，自覚症状， 肝障害はいずれる軽快したので，9月29日に退院した (Fig. 1).

肝生検は，9月 3 日(第36病日)に施行し, Fig. 2に しめすような組織像をえた。葉内に小さな巣状肝細 胞壊死が散在し，その部位に，七ルロイド色素扰よび 
Table 1 Laboratory data on admission in case 1 (1979, Aug., 4)

\begin{tabular}{|c|c|c|c|c|}
\hline Urinalysis & & Cholesterol & 55 & $\mathrm{mg} / \mathrm{dl}$ \\
\hline protein & $( \pm)$ & FBS & 111 & $\mathrm{mg} / \mathrm{dl}$ \\
\hline sugar & $(-)$ & BUN & 29.9 & $\mathrm{mg} / \mathrm{dl}$ \\
\hline urobilinogen & $(\#)$ & Creatinine & 4.6 & $\mathrm{mg} / \mathrm{dl}$ \\
\hline bilirubin & $(-)$ & amylase & 106 & u \\
\hline \multicolumn{2}{|c|}{ Blood examination } & Total protein & 4.0 & $\mathrm{~g} / \mathrm{dl}$ \\
\hline $\mathrm{RBC}$ & $270 \times 10^{4} / \mathrm{mm}^{3}$ & Albumin & 2.4 & $\mathrm{~g} / \mathrm{dl}$ \\
\hline $\mathrm{Hb}$. & $9.8 \mathrm{~g} / \mathrm{dl}$ & \multicolumn{3}{|l|}{ Serum electrolyte } \\
\hline WBC & $5200 / \mathrm{mm}^{3}$ & $\mathrm{Na}$ & 142 & $\mathrm{mEq} / \mathrm{L}$ \\
\hline Plat. & $10.4 \times 10^{4} / \mathrm{mm}^{3}$ & K & 4.5 & $\mathrm{mEq} / \mathrm{L}$ \\
\hline \multicolumn{2}{|l|}{ Blood chemistry } & $\mathrm{Cl}$ & 99 & $\mathrm{mEq} / \mathrm{L}$ \\
\hline T. bilirubin & $2.2 \mathrm{mg} / \mathrm{dl}$ & \multicolumn{3}{|c|}{ Immunological examination } \\
\hline GOT & $6600 \mathrm{u}$ & HBs Ag. & $(-)$ & \\
\hline GPT & 3010 u & HBsAb. & $(-)$ & \\
\hline LDH & $1282 \mathrm{u}$ & AFP & $200>$ & $\mathrm{ng} / \mathrm{ml}$ \\
\hline AIK-P & KAU & ESR & 21 & $\mathrm{~mm} / \mathrm{hr}$ \\
\hline $\mathrm{Ch}-\mathrm{E}$ & $0.29 \Delta \mathrm{pH}$ & CRP & +6 & \\
\hline
\end{tabular}

G $\cdot$ I therapy

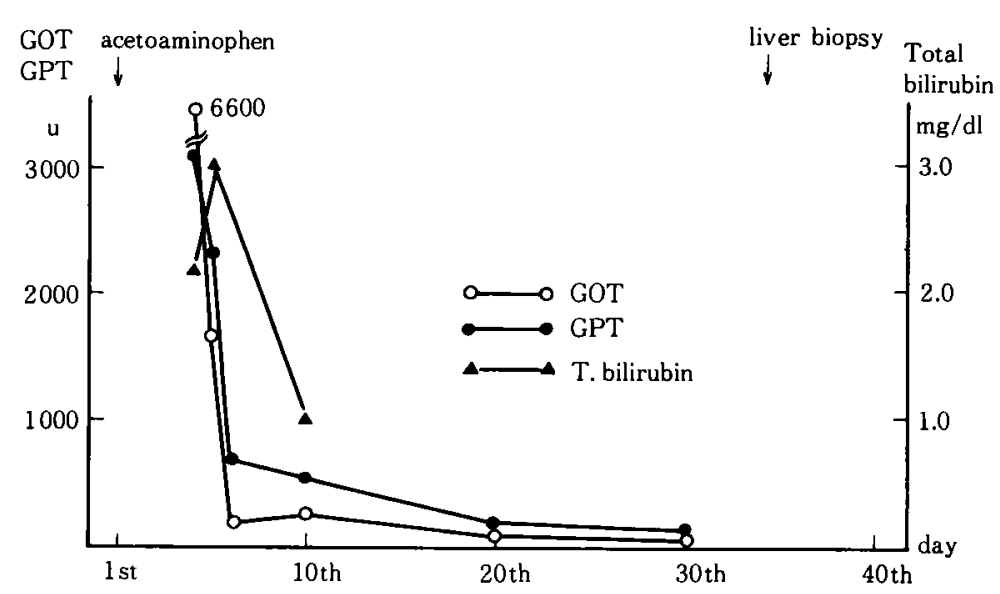

Fig. 1 Clinical course

へモジデリンを貪食したクッパー細胞の增生と，リン パ球浸潤を軽度に認めた。病変は，中心静脈周辺にお こる傾向があり，静脈周囘にも壊死が認められた。

症例 $2: 31$ 歳, 女性.

昭和57年11月 8 日, 午後 2 時頃, 自殺の目的でアセ トフミノフェン $6.4 \mathrm{~g}$ を内服した. 服用 2 日前より，ほ とんど食事を摄取しないで，絶食状態であった，11月 9 日, 意識不明で倒れているのを発見され, 同日午後 4 時に近医に入院した. 翌日, 夕方頃から覚醒したが,
心䆚部痛，呕吐および全身倦怠感を訴えた。また，血 清トランスアミナーゼが著明に上昇し，黄疸が出現し たため当科に紹介入院となった。

入院時検査所見では, GOT 1,074u, GPT 1,308u, 総 ビリルビン $3.4 \mathrm{mg} / \mathrm{d} l$ であった。 また, プロトロンビン 時間は $47 \%$ と著しく低下し, 血小板数は8.0 8 10 $/ \mathrm{mm}^{\mathrm{s}}$ であった (Table 2)。

入院時，意識障害はなく，軽度の黄㾝，肝庫大（右 季肋下 1 横指）を認めた。心肺に異常なく，神経学的 
Table 2 Laboratory data on admission in case 2 (1982, Nov., 10)

\begin{tabular}{|c|c|c|c|c|c|}
\hline \multicolumn{3}{|l|}{ Urinalysis } & BUN & 11.5 & $\mathrm{mg} / \mathrm{dl}$ \\
\hline protein & \multicolumn{2}{|l|}{$( \pm)$} & Creatinine & 1.2 & $\mathrm{mg} / \mathrm{dl}$ \\
\hline sugar & \multicolumn{2}{|l|}{$(-)$} & $\mathrm{NH}_{3}$ & 93 & $\mu \mathrm{g} / \mathrm{dl}$ \\
\hline urobilinogen & \multicolumn{2}{|l|}{$($ (\#) } & Total protein & 7.1 & $\mathbf{g} / \mathrm{dl}$ \\
\hline bilirubin & \multicolumn{2}{|l|}{$(+)$} & Albumin & 4.5 & $\mathrm{~g} / \mathrm{dl}$ \\
\hline \multicolumn{3}{|c|}{ Blood examination } & \multicolumn{3}{|c|}{ Serum electrolyte } \\
\hline $\mathrm{RBC}$ & \multicolumn{2}{|c|}{$494 \times 10^{4} / \mathrm{mm}^{3}$} & $\mathrm{Na}$ & 136 & $\mathrm{mEq} / \mathrm{L}$ \\
\hline $\mathrm{Hb}$. & \multicolumn{2}{|c|}{$16.0 \mathrm{~g} / \mathrm{dl}$} & K & 3.6 & $\mathrm{mEq} / \mathrm{L}$ \\
\hline WBC & \multicolumn{2}{|c|}{$20300 / \mathrm{mm}^{3}$} & $\mathrm{Cl}$ & 103 & $\mathrm{mEq} / \mathrm{L}$ \\
\hline Plat. & \multicolumn{2}{|c|}{$8.0 \times 10^{4} / \mathrm{mm}^{3}$} & \multicolumn{3}{|c|}{ Immunological examination } \\
\hline \multicolumn{3}{|c|}{ Blood chemistry } & \multicolumn{3}{|c|}{ HBs Ag. (-) Ab. (+) } \\
\hline T. bilirubin & 3.4 & $\mathrm{mg} / \mathrm{dl}$ & \multicolumn{3}{|c|}{$\mathrm{HBcAb} .(+)$} \\
\hline GOT & 1074 & u & \multicolumn{3}{|c|}{$\mathrm{HBeAg} \cdot(-) \mathrm{Ab} \cdot(-)$} \\
\hline GPT & 1308 & u & $\mathrm{AFP}$ & 110 & $\mathrm{ng} / \mathrm{ml}$ \\
\hline LDH & 1889 & $\mathrm{u}$ & \multicolumn{3}{|c|}{ Hepaplastin test } \\
\hline AIK-P & 6.2 & $\mathrm{KAU}$ & \multicolumn{3}{|l|}{ Prothrombin time } \\
\hline $\mathrm{Ch}-\mathrm{E}$ & \multicolumn{2}{|c|}{$0.82 \Delta \mathrm{pH}$} & \multicolumn{3}{|l|}{ ESR $\quad 28$} \\
\hline Cholesterol & \multicolumn{2}{|c|}{$200 \mathrm{mg} / \mathrm{dl}$} & \multirow[t]{2}{*}{ CRP $\quad+2$} & & \\
\hline FBS & & $\mathrm{mg} / \mathrm{dl}$ & & & \\
\hline
\end{tabular}

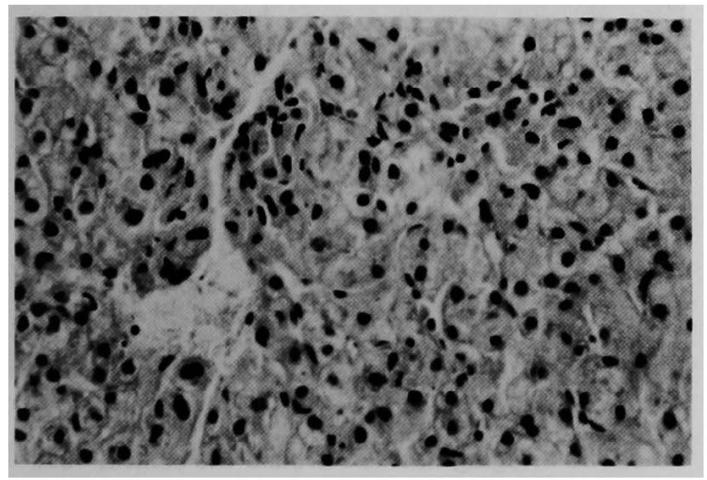

Fig. 2 Histological finding of the biopsied liver shows focal necrosis, with lymphocyte infiltration and increased number of Kupffer cells. (H.E. $\times$ 400)

検査でも正常であった。

入院後,クルカコンン・ンスリン療法を開始したと ころ, 急速に肝障害は改善していった (Fig. 3). 11月 14日より, 呕吐, 心窩部痛が悪化し, 急性胃粘膜病変 を併発したが，その後，全身状態は改善し，12月14日 に退院となった。

腹腔鏡検査は，11月24日（第17病日）に施行し，Fig. 4にしめす像をえた。肝辺縁は鋭で, 色調は淡赤色，表 面には小さな宿凹と，門脈周用の reddish marking が 散在していた。肝生検組織像では, bridging necrosis
を示す所見が認められ，セルロイド色素を含むクッ パー細胞の腫大，増生およびリンバ球の浸潤がみられ た. 中心静脈周囲の細網線維構造の虚脱が著明で, そ の部位に淡い染色性をるつ軽度の膠原線維の増生が認 められた (Fig. 5)。アセトフミノフェン肝障害に典型 的な組織像と考号らた。

\section{考察}

フセトフミノフェンの大量服用による急性肝障害 は，1966年に英国で報告”されているが，その後も本剤 は安全で速効性の鎮痛解熱剂と考えられ，安易に大量 投与されたために，あるいは，本片を含む市販薬を自 殺目的で中毒量まで服用した理由で，欧米各国で多数 の肝障害の発生をみている.1970年から3 年間に, 口 ンドンの King's College Hospital に150例以上の本剤 による急性肝障害患者が入院し，そのうち，25例は劇 症肝炎で死亡している。1976年には，約 10,000 例の中 毒患者が，英国で発生したと言われている。

フセトフミノフェンによる肝障害の発生にたいして は, 薬物代謝学的には, 以下のよ5に理解されている。 本剤は, 通常, 硫酸抱合あるいはグルクロン酸抱合に より，毒性のない極性物質に変化するが，極く少量は 肝ミクロンーム分画のチトクロームP-450を介して代 謝され，毒性中間体が生成される。この物質は，クル タチオン抱合をうけて解毒化され，メルカプッール酸 として尿中に排泄される。しかし，本剂が大量に摄取 


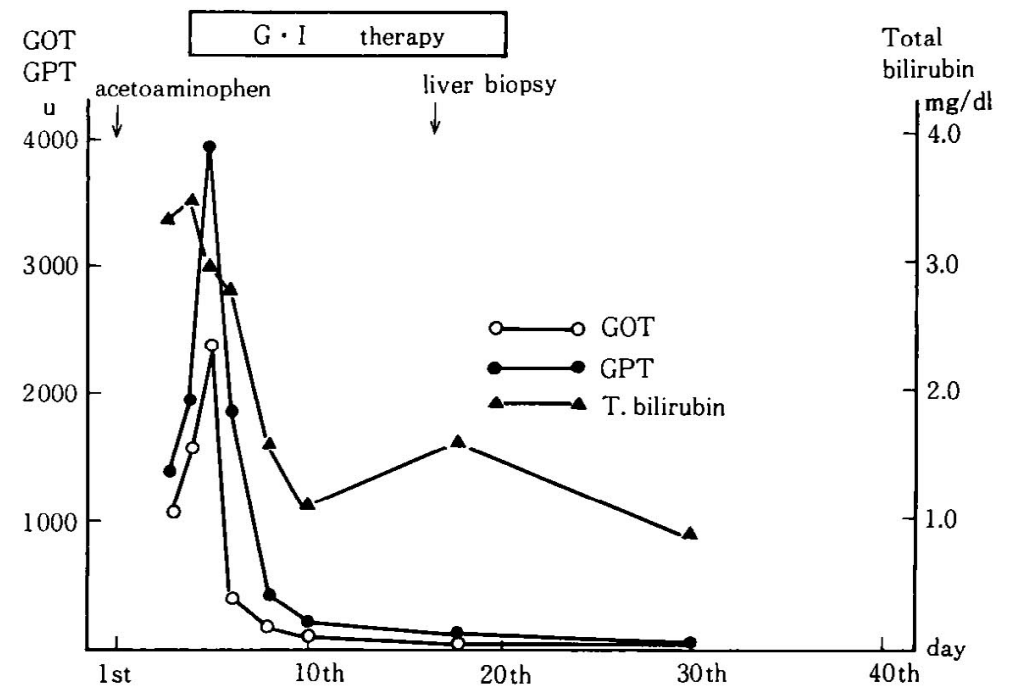

Fig. 3 Clinical course

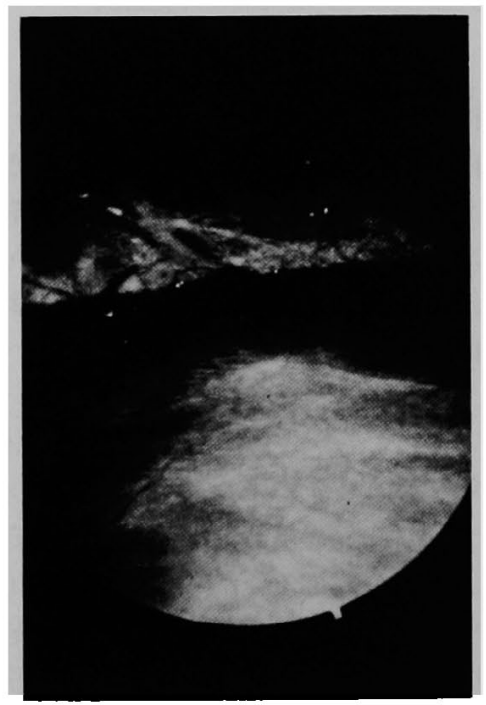

Fig. 4 Laparoscopic findings of the liver. Small depressions and peri-portal reddish markings are scattered on the liver surface.

されると，硫酸あるいはグルクロン酸抱合は飽和状態 となり，主にチトクロームP-450を介して代謝される よ5になる。このため, 肝内グルタオンが減少し， 毒性をるった中間体が大量に存在する状況となる。こ の中間体が，生体の蛋白や核酸などの高分子と反応し， 細胞障害を抗こしてくると考えられている。

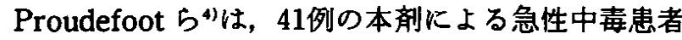
を報告し，その臨床的特徵について次のように述へて

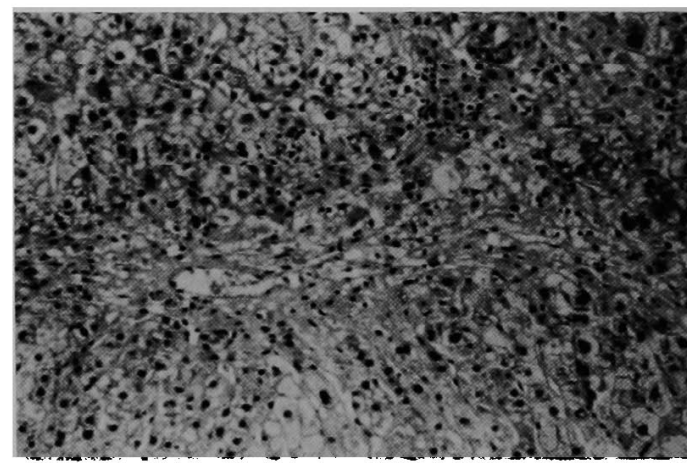

Fig. 5 Histological finding of the biopsied liver shows bridging necrosis around the central vein. (H.E. $\times 200$ )

いる. アセトアミノフェン服用後 $2 \sim 3$ 時間以内に, 本剂の直接的刺激作用に上る呕吐を生じ，24時間後か ら肝障害のために食欲不振，呕吐，心窝部痛を認める。 2 4 日啳に肝障害の程度が最も重篤になり, 黄疸が 出現する．2７日後に，急性肝壊死のために死する 例があり，14\%の死亡率であったと報告している。 た，急性尿細管壊死に㛿因する腎障害す特徵的である

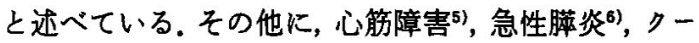

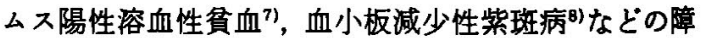
害をみることがある。

自験例では，いずれす，本剤による急性中毒に特致 的な臨床経過をたどり，消化器症状を伴った肝障害を 認めた，症例 1 では，留障害と心内膜炎，さらに急性 
膵炎, 症例 2 では血小板减少が発生した。

アセトアミノフェンによる急性肝障害の組織学的特 改は, Russell ら゚が述べているように，小葉中心部の 肝細胞壊死と細網線維構造の虚脱である. 主として, 単核細胞の浸潤を伴い，炎症の程度は様々である。病 変が小葉中心性にみられるのは, 肝ミクロンーム分画 中にある薬物代謝酵素が中心部に多く存在するためと 考えられている. Oliver ら'01は，血清トランスアミ ナーゼが正常です，軽〜中等度の肝細胞壊死をみるこ とがあり，400u 以上では重篤な壊死が認められたと報 告している。

しかし, 症例 1 では, GOT 6,600u, GPT 3,010u と 著明に上昇したにるかかわらず, 組織学的には, 障害 の程度は軽度であり, 病变の局在も特徵的ではなかっ た. 症例 2 では，本剤に典型的な組織像を示していた が，一般に肝障害を引きおこすと考えられている服用 量に比して6.4g と少ないにもかかわらず, 肝壊死の程 度は重症であった。

ところで，一般にアセトフミノフェンを $15 \mathrm{~g}$ 以上服 用すると，急性肝障害がおこると考えられている。し かし，稀に，6.2 7.5g 程度でも肝障害を生じることが あるとされているが，自験例での服用量はいずれも少 量であり，症例 1 では肝障害をおこし難い服用量で あった，また，症例 2 は服用量のわりに肝障害が重篤 であった。この点に関しては, 少量です重篤な肝障害 を惹起しらるよらな因子が併存していたためか，また， 個体の感受性あるいは薬物代謝能に相違があるためな のか，といったことが問題となろら。そこで，まず， 併存した因子について，自駼例で考察してみる.

大酒家中慢性エタノール投与ラットにおいて，本剤 による肝障害がより重篤になることが知られてい る(1).この原因としては，第一に，アルコールによる薬 物代謝酳素の誘導, 次に低蛋白食による肝内グルタチ

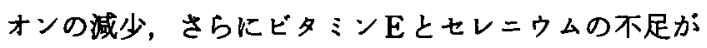
考えられている。一方，急性エタノール投与ラットに おいても，肝内グルタチンが減少すると考えられて おり, Vina ら ${ }^{(2)}$ は分離肝細胞を使い, エタノールから 生じるアセトフルデヒドが還元型タルタチオンの低下 を，数十分で引きおこすことを証明している。そこで， 症例 1 は中毒量以下の $3.7 \mathrm{~g}$ の服用であったにもかか わらず, アルコールを摄取していたことが重篤な肝障 害をまねいたと考兄られる。 また, MacLean ら アセトアミノフェン肝障害は短期間の絶食です增強さ れると報告している.これは, アミノ酸, とくにシス
ティンの不足によって肝内グルタチオンの合成が低下 し，極く少量のグルタチオンしか肝内に存在しないた めに，本剤投与後，グルタチオンの枯渴がおこり，大 量の毒性中間体が生成されるためといらことで説明さ れている。したがって, 肝障害を重症化しらる因子と

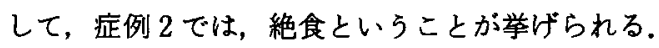

次に，個体の薬物代謝能の相違について，若干，考 察してみる. Arena ら ${ }^{14)} は$, 致死量のアセトアミ， フェンを服用し，重症の肝障害を生じたにもかかから ず，救命しえた 3 嵗の子供を報告している。また， Wilson $5^{15)}$ は, 13歳の死亡例を報告し, 幼児がアセ卜 アミノフェン肝障害に対して抵抗力がある可能性をし めしている，年齢の相違による本剤代謝経路の差異に

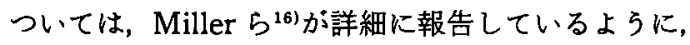
新生児は硫酸抱合で解毒し，加齢につれてその依存性 が低下し，おとなでは，グルクロン酸抱合に依存して いると考えられている。しかし，その capacityについ ての文献的報告は見あたらず，アセトアミノフェン代 謝の個体差あるいは人種差といら問題は，現在まで不 明と言わざるをえない.したがって、アセトフミノフェ ン3.7g を服用した症例 1 では, アルコールによる肝障 害の増強だけでなく，個体の代謝能の低下といった点 も，重症肝障害を惹起した原因として否定できない。

最後に，簡単ではあるか，治療について述べる，自 験例は，いずれむ治療により急速に回復したが，この 事実は, グルコン・インスリン療法が有意義な治療 であったためなのかは，不明である，ただし，最近， 著者ら ${ }^{171}$ は, クルカコンン・インスリン療法が，D-ガラ クトサミン肝障害ラットにおいて，䀒内グルタチオン を增加させることを証明しており，その点, 従来から の,クルタチオン合成に必要な SH 基の供与体として のメチオニン, システアミン, システィンあるいはグ ルタチオン自体の早期投与に準じるものであり，グル カコン・インスリン㞠法の新しい展開といえる。さら に, 本剂を除去する目的で, 血浆交換, 血液透析 ${ }^{18)}$, 活 性炭による吸着191などがおこなわれているが，すこぶ る当然である．いずれす，本剤の代謝から考えて，可 能な限り早期に施行しなければ，有効とは考之難い治 療法である。

\section{結語}

アルコール摂取あるいは絶食のために，アセトアミ ノフェン肝障害が，服用量から予想される以上に重篤 となった 2 例を報告し，文献的考察をくわえるととも に、アセトアミノフェン含剤の処方に際しての注意を 
喚起した。

$$
\text { 文 献 }
$$

1) Davidson DGD, Eastham WN: Acute liver necrosis following overdose of paracetamol. $\mathrm{Br}$ Med J 27 : 497-499, 1966

2）沖田 極, 児玉隆浩, 竹本忠良活力：肝疾患治療薬 の作用に関する基礎的研究. (2) 重症肝炎の治㞠を 目的とした glucagon-insulin 療法の基碗的研究. 肝藏 $19: 848-853,1978$

3）松田彰史：急性肝不全に対する glucagon-insulin 療法に関する研究 (1) 臨床的研究. 肝臓 21 ： $730-739,1980$

4) Proudfoot AT, Wright N : Acute paracetamol poisoning. Br Med J 5 : 557-558, 1970

5) Weston MJ, Williams R: Paracetamol and heart. Lancet $6: 536,1976$

6) Gilmore IT, Tourvas E: Paracetamol-induced acute pancreatitis $\mathrm{Br}$ Med J 19 : 753-754, 1977

7) Manor E, Mamor A, Kaufman S, et al: Massive hemolysis caused by acetaminophen. JAMA 236 : 2777-2778, 1976

8）児浦純義, 橋口洋一，田代正昭添加：薬物比よる血 小板减少。認められた紫斑病の 1 例。臨皮 32 ： 641-644, 1978

9) Russell C, Thompson RPH, Davidson AR, et al : Hepatic damage and death from overdose of paracetamol. Lancet $13: 66-69,1973$

10) Oliver J, Lesna $M$, Watson $A J$, et al: Liver damage after paracetamol oberdose. Comparision of liver function tests, fasting serum bile acids and liver histology. Lancet 27 : 579-581, 1975

11) Craig JM, Kromhout JP, Holtzman JL, et al:
Potenciation of acetamiophen hepatotoxicity by alcohol. JAMA $244: 251-253,1980$

12) Vina J, Estrela JM, Romero FJ, et al: Effect of ethanol on gluthathione concentration in isolated hepatocytes. Biochem J 188 : 542-549, 1980

13) MacLean AEM, Day PA: The effect of diet on the toxicity of paracetamol and the safety of paracetamol-methionine mixtures. Biochem Pharmacol $24: 37,1975$

14) Arena JM, Rourk MH, Sibrack, et al: Acetaminophen. Report of an unusual poison. ing. Pediatrics, $61: 68-72,1978$

15) Wilson JT, Kasantikul V, Martin D, et al: Death in adolescent following an overdose of acetaminophae and phenobarbital. Am J Dis Child 132: 466-473, 1978

16) Miller RP, Roberts RJ, Fischer LJ, et al : Acetaminophen elimination kinetics in neonates, children and adults. Cli Pharmacol Ther 19: 284-294, 1976

17）荻野昌昭：アセトアミノフェン肝障害 2 例と G-I が及注す薬物代謝系䣼素の変動について.「第 6 回 中国四国クルカゴン研究会」三好秋馬編, 広島, 1982, p33-39

18) Farid NR, Glynn JP, Kerr DNS: Haemodialysis in paracetamol selfpoisoning. Lancet $26: 396-398,1972$

19) Wilson RA, Winch J, Williams R: Rapid removal of paracetamol haemoperfusion through coated charcoal. Lancet 13: 77-79, 1973 


\title{
Two cases of acute liver injury caused by ingesting small dose of acetoaminophen
}

\author{
Mitsuru Yasunaga, Shoshi Matsuda, Makoto Murata, Masaaki Ogino, Yuji Kado, \\ Yasushi ShINKaI, Hiroshi NawATA, Tetsuro HANDA, Kenichi NodA, \\ Yohei Fukumoto, Kiwamu OKITA and Tadayoshi TAKEMoto*
}

Acetoaminophen-overdose is generally known to result in acute liver injury. In two cases, who were 38-year-old man and 31-year-old woman, severe liver injury caused by ingesting small dose of acetoaminophen was observed and they were relieved. After ingesting 3.7 and $6.4 \mathrm{~g}$ of acetoaminophen respectively, they were hospitalized because of nausea, abdominal pain and general fatigue.

In male case, endocarditis, renal dysfunction and acute pancreatitis were noted in addition to markedly increased serum transaminase accompanied with hyperbilirubinemia. Liver biopsy specimen showed the focal necrosis and thickness around the central vein.

In female case, not only severe liver dysfunction but thrombocytopenia were shown. Her liver revealed severe bridging necrosis.

In conclusion, the reason why small dose of acetoaminophen induced the severe liver injury will be due to special backgrounds in these cases, such as a fasted state and alcohol-intake.

* The 1st Department of Internal Medicine, Yamaguchi University School of Medicine (Ube) 